\title{
Assessing temporal and spatial variability in Pfiesteria piscicida distributions using molecular probing techniques
}

\author{
Kathryn J. Coyne, David A. Hutchins, Clinton E. Hare, S. Craig Cary* \\ University of Delaware Graduate College of Marine Studies, 700 Pilottown Rd, Lewes, Delaware 19958, USA
}

\begin{abstract}
The toxic dinoflagellate Pfiesteria piscicida has been identified in coastal waters and estuaries along the Atlantic coast of the United States. Estuaries in the mid-Atlantic region, in particular, have been targeted as high-risk areas for toxic blooms since reports of Pfiesteria-related fish kills in the Pocomoke River, Maryland, in 1997. The development of monitoring strategies for these areas requires that the presence of Pfiesteria be rapidly and accurately assessed. Routine monitoring by light microscopy lacks both the sensitivity and accuracy required for species-specific detection and enumeration of Pfiesteria, especially at the low levels normally found in non-bloom conditions. In this study, we developed 2 molecular techniques to identify and enumerate $P$. piscicida in the Delaware Inland Bays and the Pocomoke River. The first technique, denaturing gradient gel electrophoresis (DGGE), was used to identify several similar but distinct strains of Pfiesteria in water and their benthic stages (cysts or amoebae) in sediment samples. A comparison of DGGE analyses of Pfiesteria community structure in the Pocomoke River and the Delaware Inland Bays revealed subtle differences in strain composition. A second technique, PCR-fluorescent fragment detection (PCRFFD), was designed for quantitative enumeration of Pfiesteria in water samples. This technique offers a 1000-fold increase in sensitivity over microscopic techniques. To demonstrate the utility of PCRFFD, we conducted a study of Pfiesteria at the Roosevelt Inlet, Lewes, Delaware. Pfiesteria concentrations over 2 tidal cycles were correlated to other physical, biological and chemical variables. Overall, our data establish the presence of Pfiesteria as a minor but prevalent member of the phytoplankton community in mid-Atlantic estuaries.
\end{abstract}

KEY WORDS: Pfiesteria - Harmful algal blooms - PCR-FFD - DGGE - Delaware Inland Bays · Broadkill River · Pocomoke River · Sediments · Cysts

\section{INTRODUCTION}

The toxic marine dinoflagellate Pfiesteria piscicida poses a significant threat both to natural resources and to public health (Burkholder et al. 1992, Burkholder \& Glasgow 1997a). Massive Pfiesteria-related fish kills have been recorded since 1991 in the Albemarle-Pamlico estuaries of North Carolina, with estimates of over 1 billion fish killed in a single event (Burkholder et al.

${ }^{*}$ Corresponding author. University of Delaware, College of Marine Studies, 700 Pilottown Road, Lewes, Delaware 19958, USA. E-mail: caryc@udel.edu
1995). Aside from the economic and ecological impacts of toxic Pfiesteria blooms, evidence also exists of serious impacts on human health after contact with water containing high concentrations of toxic Pfiesteria or by inhaling aerosolized water from affected areas in a laboratory setting and in the natural environment (Glasgow et al. 1995, Grattan et al. 1998).

Tolerance to a broad range of environmental conditions indicates a potential for widespread distribution of Pfiesteria in temperate to subtropical regions (Burkholder \& Glasgow 1997a). Initially isolated from fish cultures at the North Carolina State University College of Veterinary Medicine, $P$. piscicida has been identi- 
fied in coastal waters and estuaries ranging from the Long Island Sound, New York, south to Mobile Bay, Alabama (Burkholder, et al. 1995, Lewitus et al. 1995, Rublee et al. 1999). The discovery of other closely related Pfiesteria species or strains suggests that toxic blooms could involve several members of a 'Pfiesteria species complex' (Burkholder \& Glasgow 1997a). Although the environmental factors that contribute to toxic Pfiesteria outbreaks are unclear (Burkholder \& Glasgow 1997a, Pinckney et al. 1997), the distribution and proliferation of specific strains are most likely regulated by biological, physical and chemical factors in the environment. An analysis of these factors and their relationships to the Pfiesteria community composition is essential to the prediction and prevention of toxic blooms.

Development of monitoring strategies for Pfiesteria requires that the presence of the dinoflagellate be rapidly and accurately assessed. Low-level detection of Pfiesteria in non-bloom conditions would allow us to definitively establish the organism's presence and thus its potential for future blooms. Although light microscopy is routinely used to monitor for harmful algal bloom (HAB) species in environmental samples, it does not offer the sensitivity required for detection of low abundances of $P$. piscicida and cannot be used to accurately distinguish strains of Pfiesteria. In addition, microscopic counts of Pfiesteria are often reported as presumptive counts and include all cells that resemble Pfiesteria (Pfiesteria-like organisms or PLOs). These constraints have led to the development of molecular techniques that are extremely powerful and efficient alternatives to microscopic methods for the detection and enumeration of harmful algal species (Anderson 1989, Scholin 1998, Parsons et al. 1999).

Two PCR-based methods have recently been developed to identify and enumerate Pfiesteria piscicida. Heteroduplex mobility assay-directed sequence discovery, described in Oldach et al. (2000), is an extremely sensitive method that may be used to screen cultures for contaminants or to quickly identify cloned PCR products. Its use for screening bulk DNA extracted from field samples, however, is limited because of the increased complexity of the banding patterns. A real-time PCR assay, described in Bowers et al. (2000), uses P. piscicida-specific PCR primers and probe that target unique sequences in the $18 \mathrm{~S}$ rDNA gene. This assay can be used to identify and enumerate $P$. piscicida from both cultures and environmental water samples with a sensitivity of about 0.6 cells. This specificity, however, may prevent detection of other strains or members of the Pfiesteria species complex because of sequence heterogeneity.

Our intentions in this study were to identify and assess the presence of potential members of the Pfies- teria species complex in natural Delaware and Maryland estuarine phytoplankton communities. Using molecular methods and probes that target unique sequences in the $P$. piscicida $18 \mathrm{~S}$ ribosomal DNA (rDNA) gene, we conducted a survey of Pfiesteria in 2 adjacent watersheds on the Delmarva Peninsula: the Delaware Inland Bays and the Pocomoke River, Maryland. The Pocomoke River experienced Pfiesteriarelated toxic fish kills in 1997 (Maryland Department of Natural Resources 1997). Recent Pfiesteria-related fish kills in the Delaware Inland Bays, however, have not been documented despite the presence of the dinoflagellate (Burkholder \& Glasgow 1997a). Similarities between the shallow water, highly eutrophic estuaries of the Delaware Inland Bays and other high-risk areas suggest that this area may be poised for a toxic Pfiesteria outbreak. A comparison of Pfiesteria community composition along with other biological, physical and chemical characteristics of these 2 mid-Atlantic estuarine systems would be useful in identifying factors that contribute to toxic outbreaks.

Community composition of Pfiesteria pisicida and other potential members of the Pfiesteria species complex was analyzed by comparison of banding patterns produced by denaturing gradient gel electrophoresis (DGGE) (Muyzer et al. 1993). Sequences of these bands revealed the presence of several closely related potential members of the Pfiesteria species complex. These similar but distinct strains were identified in water and sediment samples from both the Delaware Inland Bays and the Pocomoke River.

A second molecular method was designed to assess the abundance of Pfiesteria in water samples. Using a novel technique, PCR-fluorescent fragment detection (PCR-FFD), our results demonstrate the quantitative detection of low levels of $P$. piscicida in spiked samples. To demonstrate its utility, PCR-FFD was used to assess short-term variability and patchiness of Pfiesteria distributions in an area where they have not previously been reported, in the Delaware Bay at Roosevelt Inlet, Lewes, Delaware.

Overall, the results of our survey establish the widespread presence of Pfiesteria piscicida and several closely related strains in the mid-Atlantic region, and suggest that this dinoflagellate is ubiquitously distributed on the Delmarva Peninsula.

\section{MATERIALS AND METHODS}

18S rDNA sequence. Pfiesteria piscicida (North Carolina Strain 113-3B, nontoxic zoospore stage, provided by J. Burkholder, North Carolina State University) was cultured in $\mathrm{f} / 2$ medium (Guillard 1975) at $20^{\circ} \mathrm{C}$ with a mixture of cryptomonads, Storeatula major and Tele- 
aulax acuta as food sources. The cells were filtered onto a $5 \mu \mathrm{m}$ polycarbonate membrane and DNA was extracted using IsoQuick Nucleic Acid Extraction Kit (Orca Research, Inc., Bothell, Washington). The $18 \mathrm{~S}$ rDNA gene was amplified by PCR using eukaryotespecific primers Euk A (5' AACCTGGTTGATCCTGCCAGT 3') and Euk B (5' GATCC(A/T)TCTGCAGGTTCACCTAC 3') (Medlin et al. 1988) in a $50 \mu$ reaction containing $125 \mathrm{ng}$ template DNA, $0.2 \mathrm{mM}$ dNTPs, $0.5 \mu \mathrm{M}$ each primer, $1.25 \mathrm{mM} \mathrm{MgCl}_{2}, 1 \times$ Taq polymerase buffer (Promega, Madison, Wisconsin), and 0.5 units Taq Polymerase (Promega). The PCR reaction consisted of 35 cycles of $30 \mathrm{~s}$ at $94^{\circ} \mathrm{C}, 1 \mathrm{~min}$ at $55^{\circ} \mathrm{C}$, and $2 \mathrm{~min}$ at $72^{\circ} \mathrm{C}$, followed by a $5 \mathrm{~min}$ extension at $72^{\circ} \mathrm{C}$. The PCR products were cloned into TOPO II vector (Invitrogen, Carlsbad, California). Two clones were bidirectionally sequenced in their entirety using Big Dye Terminator Cycle Sequencing Ready Reaction Kit (PE Applied Biosystem, Foster City, California). Sequences were aligned using genetic data environment (Smith et al. 1994).

Collection sites. Field samples for Pfiesteria distribution determinations were collected from the Delaware Inland Bays and from transect stations along the Pocomoke River, Maryland (Fig. 1). The Delaware Inland Bays includes 3 interconnected shallow water estuaries consisting of Rehoboth Bay, Indian River Bay, and Little Assawoman Bay. They have an average lowwater depth of about 1 to $3 \mathrm{~m}$ (Horsley \& Witten 1998). These bays are tidally flushed with estimates of residence times of 90 to $100 \mathrm{~d}$ for Indian River Bay, $80 \mathrm{~d}$ for Rehoboth Bay, and with similar predictions for Little Assawoman Bay (Weston 1993). The Inland Bays have become highly eutrophic, due to excess nutrient load-

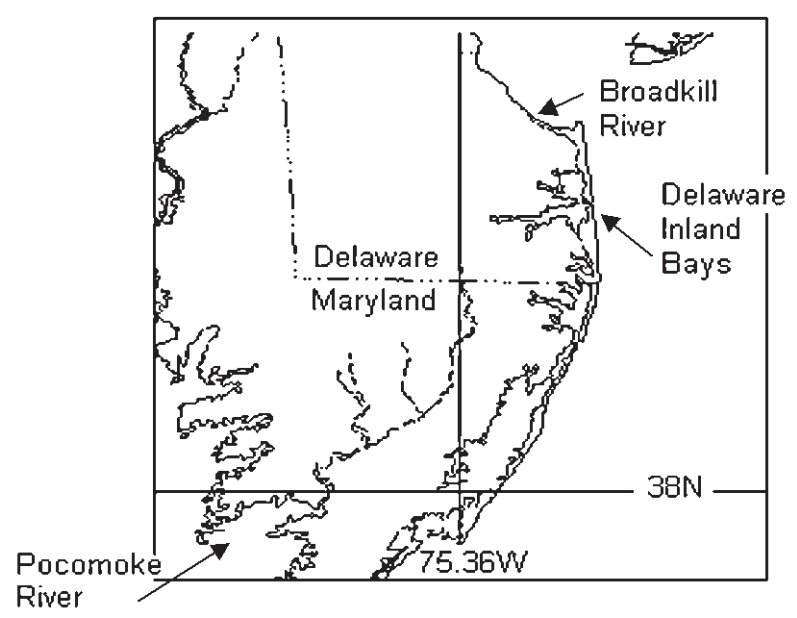

Fig. 1. Map of the Delmarva Peninsula in the mid-Atlantic region of the eastern United States including the Delaware Inland Bays, the Broadkill River, Delaware and the Pocomoke River, Maryland ing of both nitrogen and phosphorus. Excess nutrients have been implicated in the declining shellfish and finfish productivity of the bays, as well as loss of submerged aquatic vegetation and increases in algal growth leading to a decline in species diversity (Horsley \& Witten 1998, Price 1998). Samples were collected at 2 wk intervals from July 25, 1999, to October 6, 1999. Delaware Inland Bays sampling sites included Rehoboth Bay, Love Creek, Herring Creek, Indian River Bay, Indian River, Pepper Creek and Whites Creek. Samples were also collected at Little Assawoman Bay, including 2 on August 19, 1999, 24 h after a fish kill.

The second area under investigation is the Pocomoke River, Maryland (Fig. 1). This river drains forests, agricultural and poultry operations on the eastern shore of the Chesapeake Bay. The estuarine segment of the river begins at Pocomoke City, 15 miles $(\sim 24 \mathrm{~km})$ from its mouth, and opens into a broad, shallow sound before entering the Chesapeake. Exchange of water between the sound and the upper river is buffered by a 1 to $2 \mathrm{~m}$ sill (Carter 1967), resulting in relatively poor flushing. Conditions in the sound are favorable for the growth of Pfiesteria, with near optimal salinities (15) and nutrient enrichment (Maryland Department of Natural Resources Report 1997). Water samples were collected on August 9, 1999, and on August 18, 1999, along a transect starting at the mouth of the river and ending at Snow Hill, Maryland.

Water samples were collected from just below the surface of the water in 21 polystyrene containers and stored in a cooler filled with ambient water until processing. Six sediment samples were also collected from Rehoboth Bay using a grab. The surface of each sediment sample was scraped into a $50 \mathrm{ml}$ polycarbonate screw-cap tube and kept at ambient temperature until analysis. All samples were processed within $8 \mathrm{~h}$ of collection.

Water samples for PCR-FFD analysis were collected hourly over a $26 \mathrm{~h}$ period from August 3 to 4, 1999, from the College of Marine Studies Pollution Ecology Laboratory dock at the mouth of the Broadkill River, at Roosevelt Inlet, Lewes, Delaware (Fig. 1). The Broadkill River is a well-mixed coastal plain estuary $17.4 \mathrm{~km}$ in length (Dewitt \& Daiber 1973). It has 2 major sources of nutrients and organic matter, the fresh and salt marshes (non-point source) and a sewage outfall near Milton, Delaware (point source). The lower $4 \mathrm{~km}$ of the Broadkill River is roughly a straight extension of the Lewes and Rehoboth Canal, which connects the Delaware Bay to the Rehoboth Bay. This part of the estuary is sectionally homogeneous during $90 \%$ of each tidal cycle, maintained by strong tidal currents. Stratification only occurs for a short interval at the beginning of each flood tide (Dewitt \& Daiber 1973). The sampling site is a shallow (2 to $3 \mathrm{~m}$ ), well-flushed 
tidal channel subject to strong physical forcing as water is exchanged between the tidal river and the adjacent Delaware Bay (Dewitt \& Daiber 1973).

DNA extraction. From each water sample, 100 to $300 \mathrm{ml}$ was pre-filtered through $20 \mu \mathrm{m}$ polycarbonate filters (Osmonics, Livermore, California) to remove zooplankton, large diatoms and detritus. The $20 \mu \mathrm{m}$ filtrate was then filtered a second time through $5 \mu \mathrm{m}$ polycarbonate filters to collect the plankton size fraction that includes Pfiesteria (5 to $10 \mu \mathrm{m}$ ). Maximum vacuum pressure for all filtering was $3 \times 10^{4} \mathrm{~Pa}$. The $5 \mu \mathrm{m}$ membranes were placed in $0.6 \mathrm{ml} \mathrm{CTAB}$ extraction buffer, $100 \mathrm{mM}$ Tris-HCl (pH 8), $1.4 \mathrm{M} \mathrm{NaCl}, 2 \%$ (w/v) cetyltrimethylammonium bromide (CTAB), $0.4 \%$ (v/v) $\beta$-mercaptoethanol, $1 \%$ (w/v) polyvinylpyrollidone (Dempster et al. 1999), heated to $50^{\circ} \mathrm{C}$ for 20 to $40 \mathrm{~min}$ and stored at $-80^{\circ} \mathrm{C}$ until extraction. Sediment samples were processed by addition of $2 \mathrm{ml}$ CTAB extraction buffer per gram of sediment. The mixture was incubated at $50^{\circ} \mathrm{C}$ for 20 to $40 \mathrm{~min}$ and stored at $-80^{\circ} \mathrm{C}$ until extraction. All samples were heated in a $65^{\circ} \mathrm{C}$ water bath for 5 to $10 \mathrm{~min}$ immediately before extraction. Nucleic acids were extracted as described in Dempster et al. (1999). The DNA for each sample

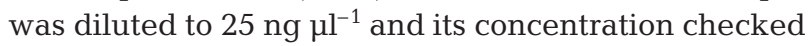
by ultraviolet spectrophotometry at $260 \mathrm{~nm}$.

Cysts. Cysts were collected either on sterile sediments or on microscope slide cover slips $(22 \times 22 \mathrm{~mm})$ from Pfiesteria piscicida culture that had been kept in the dark for $1 \mathrm{wk}$. The cysts adhering to the cover slip or sediments were rinsed in sterile $f / 2$ media and examined by microscope to make sure that no flagellated zoospores were present. Approximately 100 to 200 cysts had adhered to each cover slip examined. To test the efficiency of the extraction and to test for PCR inhibition by sediments, DNA was extracted from the cysts under 3 different conditions using the extraction protocol described above. In the first treatment, DNA was extracted from the cysts adhering to the cover slip by crushing the cover slip in $0.6 \mathrm{ml}$ CTAB extraction buffer. This was repeated for the second treatment except that $0.3 \mathrm{~g}$ nonsterile sediments were added to the extraction to test for PCR inhibition. DNA was also extracted from $0.3 \mathrm{~g}$ nonsterile sediments (without Pfiesteria cysts) as a negative control. For the third treatment, DNA was extracted from Pfiesteria that had encysted onto sterile sediments.

The DNA (20 ng) was amplified by PCR in $20 \mu \mathrm{l}$ reactions containing $0.2 \mathrm{mM}$ dNTPs, $2.5 \mathrm{mM} \mathrm{MgCl}_{2}, 1 \times \mathrm{Taq}$ polymerase buffer (Promega), 0.5 units Taq Polymerase (Promega), $0.5 \mu \mathrm{M}$ Pfiesteria piscicida-specific primer Pfp306R (5' GTCAGAAAGTGATATGGTATAT $3^{\prime}$ ) and $0.125 \mu \mathrm{M}$ Euk $\mathrm{A}$. The PCR reaction consisted of 35 cycles of $30 \mathrm{~s}$ at $94^{\circ} \mathrm{C}, 30 \mathrm{~s}$ at $56^{\circ} \mathrm{C}$ and $1 \mathrm{~min}$ at $72^{\circ} \mathrm{C}$, followed by a $5 \mathrm{~min}$ extension at $72^{\circ} \mathrm{C}$.
DGGE analysis. DGGE was performed as described in Muyzer et al. (1993). DNA (125 ng) was amplified by $\mathrm{PCR}$ in $50 \mu \mathrm{l}$ reactions containing $0.2 \mathrm{mM}$ dNTPs, 2.5 $\mathrm{mM} \mathrm{MgCl} 2,1 \times$ Taq polymerase buffer (Promega), 0.25 units Taq Polymerase (Promega), 0.25 units Pfu Polymerase (Stratagene, La Jolla, California), 0.5 $\mu \mathrm{M}$ Pfiesteria piscicida-specific primer Pfp306R and $0.125 \mu \mathrm{M}$ Euk A-GC (5' CGCCCGCCGCGCCCCGCGCCCGTCC CGCCGCCCCCGCCAACCTGGTTGATCCGCCAGT3').

The PCR reaction consisted of 37 cycles of $1 \mathrm{~min}$ at $94^{\circ} \mathrm{C}, 30 \mathrm{~s}$ at $56^{\circ} \mathrm{C}$ and $1 \mathrm{~min}$ at $72^{\circ} \mathrm{C}$, followed by a $5 \mathrm{~min}$ extension at $72^{\circ} \mathrm{C}$. Between 20 and $40 \mu \mathrm{l}$ of the PCR products were loaded directly onto a $6 \%$ polyacrylamide gel with a gradient of 25 to $45 \%$ denaturant $(100 \%$ denaturant corresponds to $7 \mathrm{M}$ urea, $40 \%$ formamide). Electrophoresis was carried out for $5.5 \mathrm{~h}$ at $130 \mathrm{~V}, 60^{\circ} \mathrm{C}$ using a Dcode Universal Mutation Detection System (Bio-Rad, Hercules, California). Fractionated PCR products were stained with ethidium bromide $\left(0.5 \mathrm{mg} \mathrm{ml}^{-1}\right)$ and visualized on a UV transilluminator. The image was captured using the AlphaImager System (Alpha Innotech Corp., San Leandro, California) and edited for size using Microsoft Photo Editor (Microsoft Corp, Seattle, Washington).

Individual DGGE bands were isolated for sequencing by stabbing with an aerosol-free pipette tip and resuspending in $27 \mu \mathrm{l}$ water. Of the isolated DNA, $10 \mu \mathrm{l}$ was reamplified under the same conditions described above and checked for purity by DGGE. PCR products were purified with Qiagen PCR Purification columns (Qiagen, Valecia, California) and sequenced using Big Dye Terminator Cycle Sequencing Ready Reaction Kit (PE Applied Biosystem Inc.).

Spiked samples. Water was collected from Red Mill Pond, Lewes, Delaware, and pre-filtered through a $20 \mu \mathrm{m}$ polycarbonate membrane. Four $250 \mathrm{ml}$ portions of the filtrate were filtered a second time through $5 \mu \mathrm{m}$ filters. This was followed by a volume of Pfiesteria culture (113-3B) to yield the equivalent of $0,1,10$ and 100 Pfiesteria cells $\mathrm{ml}^{-1}$ of field sample, based on microscopic counts of a concentrated laboratory culture. The $5 \mu \mathrm{m}$ filters were treated as described above for field samples. The DNA for each spiked sample was diluted to $25 \mathrm{ng} \mathrm{ul}^{-1}$ and its concentration checked by ultraviolet spectrophotometry at $260 \mathrm{~nm}$. Further dilutions were made in DNA (25ng $\left.\mathrm{\mu l}^{-1}\right)$ extracted from field samples (negative for Pfiesteria) to achieve spiked standard concentrations ranging from 0.01 to 100 Pfiesteria cells $\mathrm{ml}^{-1}$.

Enumeration by PCR-FFD. The concentrations of Pfiesteria piscicida in spiked standards and field samples were determined by PCR-fluorescent fragment detection (PCR-FFD). PCR-FFD is similar to methods previously described (Porcher et al. 1992, Lu et al. 1994) with some modifications. PCR-FFD consists of a 
PCR amplification followed by detection of HEXlabeled PCR products on an ABI Prism 310 Genetic Analyzer (PE Applied Biosystems) using GeneScan software. Positive PCR products were identified by retention time during capillary electrophoresis and quantified by peak area.

DNA (50 ng) was amplified by PCR in duplicate $20 \mu$ reactions using the Pfiesteria piscicida-specific primer Pfp306R and a fluorescently labelled primer, Euk A-HEX. The PCR reaction consisted of 31 cycles of $30 \mathrm{~s}$ at $94^{\circ} \mathrm{C}, 30 \mathrm{~s}$ at $56^{\circ} \mathrm{C}$ and $1 \mathrm{~min}$ at $72^{\circ} \mathrm{C}$, followed by a $5 \mathrm{~min}$ extension at $72^{\circ} \mathrm{C}$. The appropriate number of cycles of PCR amplification was determined empirically to avoid reaching the plateau phase for each of the spiked standards. After amplification, duplicate samples were pooled and $1 \mu \mathrm{l}$ of the pooled reaction was resuspended in $19 \mu \mathrm{l}$ of deionized formamide containing $2.5 \%$ (v/v) TAMRA sizing standard (PE Applied Biosystems). After denaturation at $95^{\circ} \mathrm{C}$ for $2 \mathrm{~min}$, the fluorescent PCR products were loaded on an ABI Prism 310 Genetic Analyzer (PE Applied Biosystems) equipped with a $47 \mathrm{~cm}$ capillary. Samples were electrophoresed for $22 \mathrm{~min}$. using a $5 \mathrm{~s}$ injection at $15 \mathrm{kV}$. PCR products were detected and quantified by GeneScan v.3.1 (PE Applied Biosystems).

The detection variability between injections was minimized by using the GeneScan (TAMRA) Size Standard (PE Applies Biosystems) as an internal standard. For each sample injection, the area of the peak corresponding to the HEX-labeled PCR product at $311 \mathrm{bp}$ was normalized to the area of the TAMRAlabeled size standard peak at $300 \mathrm{bp}$. The PCR product/internal standard mixture was further diluted in formamide if the peak corresponding to the PCR product was off scale. Variability in the peak area ratios of PCR product to the TAMRA internal standard was minimal (within 3\%) with dilutions up to 20 -fold in formamide (data not shown).

A standard curve was generated from spiked standards for each set of samples tested. Pfiesteria piscicida concentrations in cells $\mathrm{ml}^{-1}$ were calculated by linear regression analysis. Some variability in biomass was presumed for equivalent volumes of field samples and spiked standards. The amount of DNA template used for each PCR reaction, however, was kept constant (50 ng) to minimize variability due to fluctuating DNA concentrations. For this reason, the ratio of chlorophyll a concentrations (sample:standard) was used as a dilution factor to more closely approximate the volume of field sample represented by $50 \mathrm{ng}$ of PCR template. In this way, the outcome was not dependent upon a quantitative extraction protocol, but rather on the concentration of targeted template DNA within the total DNA extracted.
Chlorophyll a determination. Total chlorophyll a was measured by fluorometry for all experiments with spiked and natural water samples. Between 50 and $100 \mathrm{ml}$ sample water was vacuum-filtered onto $47 \mathrm{~mm}$ GF/F glass fiber filters (Whatman) and extracted in $10 \mathrm{ml} 90 \%$ acetone in the dark at $4^{\circ} \mathrm{C}$ for 24 to $48 \mathrm{~h}$ before analysis (Strickland \& Parsons 1972).

Nutrients, temperature and salinity measurements. Samples were collected for dissolved nitrate plus nitrite, phosphate and silicic acid analyses using an Alpkem autoanalyzer. Temperature and salinity were measured every $15 \mathrm{~min}$ by an Endeco/YSI 600 XLM multi-parameter water quality monitor.

Bacterial cell counts. Bacteria were enumerated by epifluorescent direct counts of acridine orange-stained samples (Hobbie et al. 1977). Samples were fixed with a final concentration of $4 \%$ filtered glutaraldehyde. Slides were made within $3 \mathrm{~d}$ of collection by filtration of $1 \mathrm{ml}$ samples onto $25 \mathrm{~mm}, 0.1 \mu \mathrm{m}$ black polycarbonate filters. Slides were kept in the dark at $4^{\circ} \mathrm{C}$ until counting by epifluorescence light microscopy.

\section{RESULTS}

\section{S rDNA sequence}

Two recombinant clones designated S3-3 and S7-14 prepared from PCR products of the $18 \mathrm{~S}$ rDNA extracted from cultured Pfiesteria piscicida (113-3B) were bidirectionally sequenced. The sequences matched the $P$. piscicida $18 \mathrm{~S}$ rDNA sequence deposited in GenBank (Accession number AF077055, Oldach et al. 2000). A P. piscicida-specific primer, Pfp306R, was designed by aligning the sequence with other dinoflagellate 18S rDNA sequences available in GenBank and checked against all eukaryotic sequences in the Ribosomal Database (Ribosomal Database Project II, Maidak et al. 1999).

\section{DNA extraction}

DNA was extracted from the 5 to $20 \mu \mathrm{m}$ size fraction of environmental water samples, eliminating a large portion of plankton, bacteria and detritus. We found that this improved amplification efficiency and was critical to the success of this project. By eliminating bacteria and larger zooplankton, variability between samples was reduced and allowed us to normalize biomass to chlorophyll for samples collected from different locations. Although some amoeboid stages of Pfiesteria piscicida are larger than $20 \mu \mathrm{m}$, it is unlikely that these stages would be present near the surface of the water. The selective filtration protocol described here 


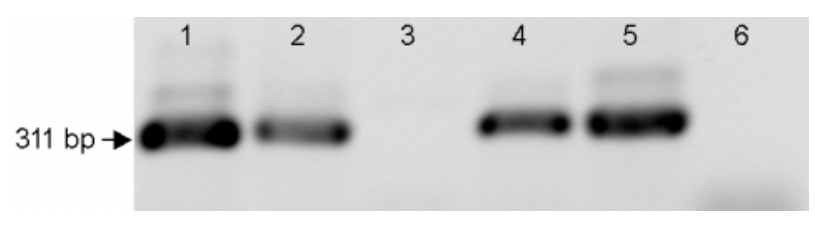

Fig. 2. PCR amplification of DNA extracted from Pfiesteria piscicida cysts alone or in the presence of sediments. Lane 1 , amplification of cysts alone; lane 2, amplification of cysts in the presence of nonsterile sediments; lane 3, negative control (DNA extracted from nonsterile sediments alone); lane 4, amplification of $P$. piscicida encysted onto sterile sediments; lane 5, positive PCR control; lane 6, negative PCR control

would have to be varied for target species that fall outside the 5 to $20 \mu \mathrm{m}$ size range.

\section{Cysts}

To assess our ability to extract and amplify DNA from Pfiesteria piscicida cysts in the presence of sediments, we induced encystment onto either sterile glass cover slips or onto sediments that had been sterilized by autoclaving. The DNA extracted from the cysts was amplified by PCR using the $P$. piscicida-specific primer Pfp306R and Euk A. Results shown in Fig. 2 validate the CTAB extraction method for use on sediments and for extraction of $P$. piscicida cysts in the sediments.

\section{DGGE analysis}

DGGE was performed using a GC-clamped universal eukaryotic 18S rDNA forward primer, Euk A-GC, and the Pfiesteria piscicida-specific reverse primer Pfp306R. PCR products resulted in a $311 \mathrm{bp}$ fragment. The amplified PCR product from cultured $P$. piscicida (113-3B) resulted in a single band with DGGE (data not shown). Its migration matched the migration of PCR products amplified from the sequenced18S rDNA clone, S3-3. DGGE analysis of amplified DNA from water and sediment samples, however, resulted in up to 6 distinct bands, including a band corresponding to the known toxic strain of P. piscicida (113-3b) (Fig. 3A). The other 5 bands were designated 17B, 14B, 20B, $8 \mathrm{~A}$ and $4 \mathrm{~B}$. The intensities of bands corresponding to $17 \mathrm{~B}, 14 \mathrm{~B}$ and P. piscicida are always at least as intense as, and most often are more intense than, bands 20B, $8 \mathrm{~A}$ and $4 \mathrm{~B}$. Faint or fuzzy bands (indicated by arrows on Fig. 3A) occurred on occasion but could not be isolated for sequencing. Replicates of each of the 6 major bands were picked from DGGE gels, individually reamplified and sequenced (GenBank Accession numbers AF363585 to AF363589). The sequences of the 5 bands with mi- gration patterns that differed from $P$. piscicida were aligned with sequences from both $P$. piscicida and $P$. shumwayae (GenBank Accession number AF218805). The sequences of bands $8 \mathrm{~A}$ and $17 \mathrm{~B}$ differed by 1 base $(0.3 \%)$ from P. piscicida. Bands corresponding to $4 \mathrm{~B}$, 14B and 20B each differed by 2 bases $(0.6 \%)$. For comparison, $P$. shumwayae differs from $P$. piscicida by 31 bases $(10 \%)$ in the $311 \mathrm{bp}$ region of interest.

Altogether, 85 water samples were analyzed from the Delaware Inland Bays: 47 from Indian River Bay, 33 from Rehoboth Bay and 5 from Little Assawoman Bay. Thirty samples were analyzed from the Pocomoke River. A summary of DGGE band frequency for positive PCR reactions from water samples collected from the Pocomoke River, Rehoboth Bay and Indian River
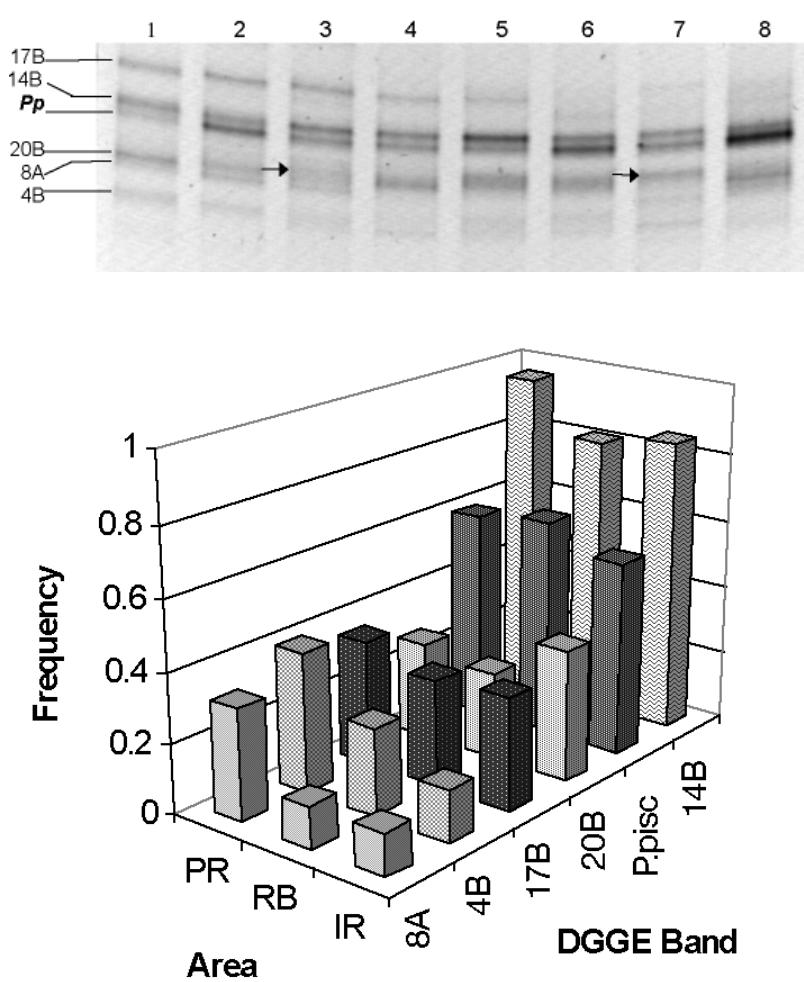

Fig. 3. (A) DGGE gel analysis of PCR amplification products of 18S rDNA using a Pfiesteria piscicida-specific primer, Pfp306R. DNA was extracted from water samples collected from 8 stations in the Delaware Inland Bays on 27 July 1999. Lanes 1, 3, 5 and 8 represent stations in the Indian River Bay. Lanes 2, 4 , 6 and 7 are from stations in the Rehoboth Bay. Samples are ordered on the gel to highlight similarities in the banding pattern. Six major bands are labeled at the left of the gel. $P p$, band corresponding to P. piscicida sequence. Arrows indicate possible heteroduplex bands that could not be isolated. (B) Frequency of DGGE bands corresponding to P. piscicida and 5 other potential strains of the Pfiesteria species complex in the Indian River Bay (IR), the Rehoboth Bay, Delaware (RB) and the Pocomoke River, Maryland (PR). 'Frequency' refers to the fraction of positive PCR products with the DGGE band indicated 
Bay is presented in Fig. 3B. Little Assawoman Bay is not included in this figure because only 2 of the 5 samples collected were positive for Pfiesteria. Overall, $69 \%$ of the field samples tested in 1999 were positive for Pfiesteria using the PCR primers and conditions described above. Bands corresponding to either 14B, or to $P$. piscicida, or both, were always present in DGGE banding patterns of positive PCR products and appeared most frequently overall (84.6 and 57.7\%, respectively). Bands corresponding to $17 \mathrm{~B}, 20 \mathrm{~B}, 4 \mathrm{~B}$ and $8 \mathrm{~A}$ occurred in $33.3,30.8,24.4$ and $17.9 \%$ of the positive samples, respectively. When comparing sites, the most frequent bands appearing in the DGGE analysis of Delaware Inland Bays samples were 14B $(79.2 \%)$, and $P$. piscicida $(56.6 \%)$, followed by $17 \mathrm{~B}$ (32.1\%), 20B (32.1\%), 4B (17.0\%) and 8A (11.3\%). For the Pocomoke River, the most frequently occurring bands in the DGGE analysis were also $14 \mathrm{~B}$ and $P$. piscicida (96.0 and $60.0 \%$ of the samples, respectively), followed by $4 \mathrm{~B}(40 \%), 17 \mathrm{~B}(36 \%), 8 \mathrm{~A}(32 \%)$ and $20 \mathrm{~B}$ (28\%).

Four sediment samples (out of 6) collected from the Rehoboth Bay, Delaware, were positive for Pfiesteria. Bands corresponding to 14B occurred in all 4 positive samples and bands corresponding to Pfiesteria piscicida occurred in 2 of the samples. 17B, 20B and 4B were also present in 1 sample.

\section{Enumeration by PCR-FFD}

Enumeration of Pfiesteria piscicida strains detected by DGGE was achieved by PCR-FFD. Since the amplified sequences of all 6 strains were identical in size, PCR-FFD analysis was used here to quantify the total number of cells of all strains of $P$. piscicida in a sample. Standard curves of spiked standards demonstrated a detection sensitivity of 10 cells $\mathrm{l}^{-1}$ and were linear over 3 orders of magnitude $\left(\mathrm{R}^{2}=0.9821\right.$, Fig. 4). The accuracy of the method was tested on a second set of spiked samples. Sample A contained 1 cell ml $\mathrm{m}^{-1}$ and sample B contained 10 cells ml ${ }^{-1}$. PCR-FFD analysis of triplicate PCR reactions yielded 5, 3 and 1 cells $\mathrm{ml}^{-1}$ for the spiked sample A and 11, 14 and 8 cells ml-1 for spiked sample B. Sources of error include variability between PCR reactions, variability in subsampling the culture when preparing the spiked samples and errors in microscopic counts of the original culture.

In this study, we used spiked standards from a single location to generate the standard curve. It is likely that the plankton community and chlorophyll content of samples from different locations or from the same location at different times of year may vary significantly from the spiked standards. In this case, it may be necessary to prepare a standard curve for each location.

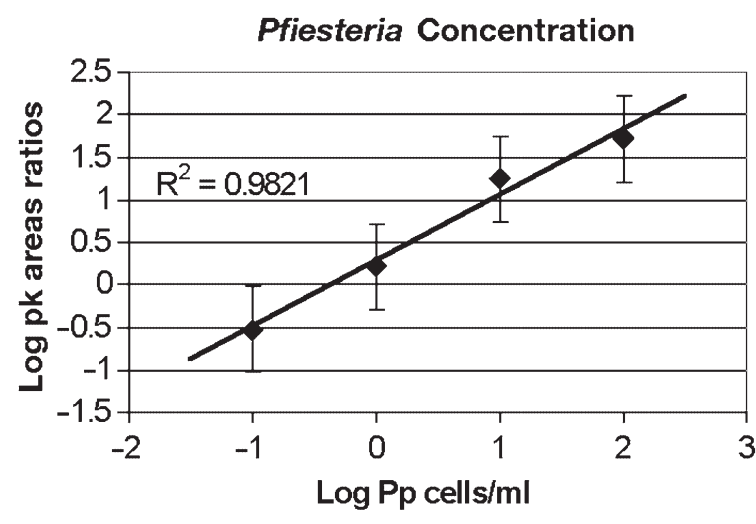

Fig. 4. Log plot of Pfiesteria piscicida concentration (cells ml ${ }^{-1}$ ) in spiked standards versus peak area ratio (Hex-labeled PCR product:TAMRA size standard). Error bars represent standard error

\section{Field demonstration of PCR-FFD}

DNA extracted from field samples collected from Roosevelt Inlet, Lewes, Delaware, over a $26 \mathrm{~h}$ period was subjected to DGGE analysis. DGGE banding pattern revealed the presence of 2 major bands corresponding to Pfiesteria piscicida and 20B (data not shown). A faint band corresponding to 4B was also present.

Concentrations of Pfiesteria in the samples collected from the Roosevelt Inlet were too low to count by visual microscopy. However, amplification and enumeration by PCR-FFD confirmed the presence of low levels of Pfiesteria (Fig. 5E), ranging from 10 cells $\mathrm{l}^{-1}$ (the lower limits of our detection) to 1000 cells $\mathrm{l}^{-1}$.

A visual comparison of PCR-FFD-derived Pfiesteria abundance to several environmental and biological variables over 2 tidal cycles is presented in Fig. 5. Silicate and orthophosphate concentrations showed variability driven by tidal fluctuations, with higher concentrations during slack low water conditions than during flood tide or high water (Fig. 5A). Correlations between silicate and phosphate and salinity were highly significant at the $\mathrm{p}<0.001$ level (SPSS Pearson's correlation). Nitrate concentrations, however, were more variable and showed no relationship to tidal cycles or salinity ( $p=0.42$, Fig. 5A). No correlation was noted between the concentration of nitrate or silicate and Pfiesteria abundance at the $\mathrm{p}<0.05$ level, but cell numbers did correlate with orthophosphate concentrations ( $\mathrm{p}=0.008$, Fig. 5A).

Diel patterns in Pfiesteria abundance were not strongly developed, and showed little relationship to the tidal cycle (Fig. 5E). Bacterial numbers increased during flood and high tides and were often lower during the rest of the cycle (Fig. 5C), suggesting that a 


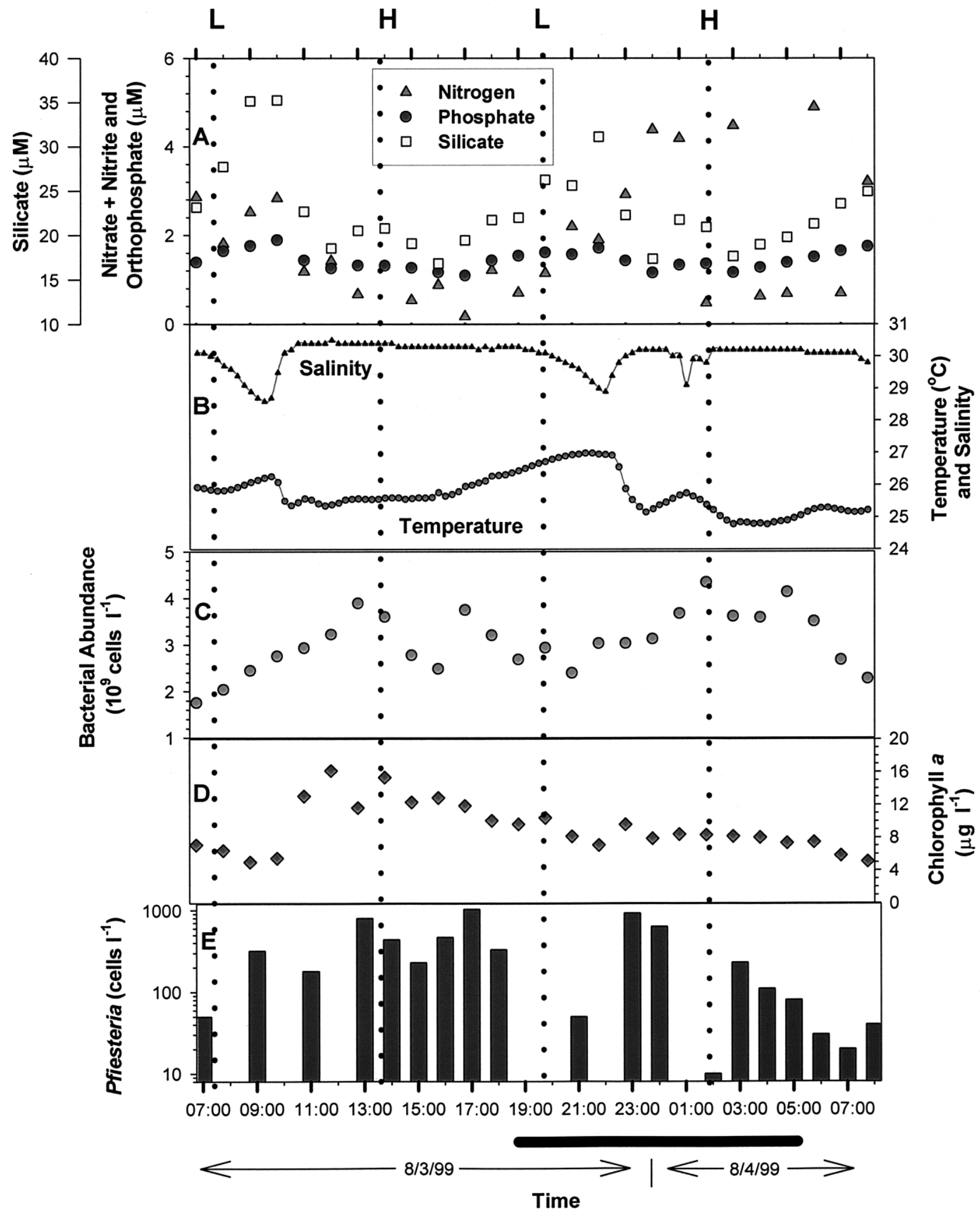

Fig. 5. Field demonstration of PCR-FFD enumeration of Pfiesteria. (A) Major nutrients (nitrate + nitrite, orthophosphate, silicates) in $\mu \mathrm{M}$ concentration. (B) Temperature $\left({ }^{\circ} \mathrm{C}\right.$ ) and salinity. (C) Bacterial abundance in $10^{9}$ cells $l^{-1}$. (D) Chlorophyll $a$ in $\mu g l^{-1}$. (E) Pfiesteria abundance in cells $1^{-1}$ measured by PCR-FFD. All panels are shown over a common $X$-axis of time (date given as $\mathrm{mo} / \mathrm{d} / \mathrm{yr})$. The heavy black line at the bottom of the figure represents the period of darkness. Slack water for high tide (H) and low tide $(\mathrm{L})$ is shown by the vertical dotted lines 
major source of bacteria to the river may be from the open Delaware Bay. Chlorophyll a concentrations showed a similar pattern during the day but not at night (Fig. 5C,D).

\section{DISCUSSION}

Our intentions were to develop molecular probes to identify and enumerate potential members of the Pfiesteria species complex in naturally occurring phytoplankton communities of 2 mid-Atlantic estuarine systems. The Delmarva Peninsula has been targeted as a high-risk area for Pfiesteria blooms. Reports of Pfiesteria-related fish kills and fish with lesions were reported in the Pocomoke River in October 1996, April/May 1997, and August 1997 (Maryland Department of Natural Resources Report, 1997). P. piscicida and other members of the Pfiesteria species complex were identified in water collected from these sites and bioassays confirmed the presence of toxic zoospores. Recent Pfiesteria-related fish kills in the Delaware Inland Bays, however, have not been documented, although a small fish kill reported in 1988 (Miller 1989) may have been due to Pfiesteria toxicity (Burkholder et al. 1995). Despite the absence of toxic activity, PLOs are frequently identified during routine monitoring of the Inland Bays. In 1997, PLOs were identified in water collected from the upper Indian River at a density $>300$ cells $\mathrm{ml}^{-1}$ (Edythe Humphries, DNREC, pers. comm.); however, no adverse effects on marine life were reported at that time.

In this study, DGGE of amplified DNA extracted from field samples confirmed the widespread presence of Pfiesteria piscicida in the mid-Atlantic estuarine system. In addition to the known toxic strain of $P$. piscicida (113-3B), at least 5 other co-occurring closely related strains were present. The DGGE band corresponding to $14 \mathrm{~B}$ was represented most frequently in samples that were positive for Pfiesteria, suggesting that the North Carolina strain (113-3B) may not be a suitable reference strain for identification of Pfiesteria in the mid-Atlantic region. The 18S rDNA sequences of each of the 5 strains vary from the $P$. piscicida sequence by less than $1 \%$ over the $311 \mathrm{bp}$ region of interest.

The presence of several genetically distinct strains of Pfiesteria piscicida is not unexpected. Intraspecies genetic variability in phytoplankton groups is a common phenomenon (reviewed by Wood \& Leatham 1992, Gallagher 1998). Geographical and seasonal differences in the presence of specific strains of some species are well documented (e.g. Skeletonema costatum, Gallagher 1982; and Pseudo-nitzschia species, Parsons et al. 1999). Contemporaneous populations of genetically distinct strains of bloom-forming species have also been noted, and suggest that the progression of a bloom may be influenced by individual strains (Skov et al. 1997). That is, changes in environmental conditions resulting from increased numbers of one strain may stimulate growth in another strain. Intraspecies genetic variability may also reflect differences in toxin production. Co-existing strains of Pseudo-nitzschia pseudodelicatissima in Louisiana coastal waters, for example, were found to vary in domoic acid production, and were dominated by nontoxic members (Parsons et al. 1999). Significant differences were also found in the toxin profiles of Alexandrium ostenfeldii isolates from different geographical regions along the New Zealand coastline (Mackenzie et al. 1996). Strain designations for $P$. piscicida have recently been suggested and include a 'non-inducible' (never toxic) assignment for those strains that cannot be induced to kill fish in laboratory bioassays (Pfiesteria Interagency Coordination Workgroup, Glossary of Pfiesteria-Related Terms, URL: http://habserv1.whoi.edu/pfiesteria/glossary.html). Whether or not these designations can be applied to strains in the natural environment remains to be seen.

The existence of several strains of Pfiesteria piscicida presents additional challenges in the study of this species. DGGE analysis could be used in high-risk areas to rapidly assess the presence of specific strains of Pfiesteria, including those that have a demonstrated potential for toxicity. DNA extracted from field samples collected following fish kills at Bullbeggar's Creek (a tributary of the Pocomoke River, July 23, 1999), and Little Assawoman Bay (August 18, 1999), for example, were analyzed by DGGE. Although assays suggested that these fish kills were not due to toxic Pfiesteria, DGGE analysis showed the presence of a band corresponding to a known toxic strain of $P$. piscicida (113-3B) along with bands corresponding to 14B, 20B and 8A, in 2 samples collected at the Bullbeggar's Creek immediately following the fish kill (within $24 \mathrm{~h}$ ). DGGE analysis of samples collected from Little Assawoman Bay in an area where dead fish were found revealed the presence of a band corresponding to $14 \mathrm{~B}$. Bands corresponding to both $14 \mathrm{~B}$ and the known toxic strain of $P$. piscicida (113-3B), however, were represented in the DGGE analysis of samples collected at a nearby site where the fish kill was thought to have actually occurred (Edythe Humphries, DNREC, pers. comm.).

DGGE analysis of sediment samples collected from the Delaware Inland Bays revealed that the same strains of Pfiesteria present in the water column can also be found in the sediments, probably as cysts or amoeboid stages of the life cycle (Burkholder \& Glasgow 1997b). Since toxic $P$. piscicida cells rapidly encyst following a fish kill, this methodology could be used to 
identify areas that are at risk for future blooms as well those areas that have experienced toxic blooms in the past. DGGE analysis of discrete sections from sediment cores may also provide a timeline of past toxic events, and changes in the Pfiesteria community that lead to these events.

The second objective of our study was to develop enumeration capabilities independent of microscopic techniques. Although the accuracy of the method is ultimately dependent upon accurate cell counts for preparing the spiked standards, quantitative analysis by PCR-FFD offers greater accuracy, sensitivity and ease of processing for determining Pfiesteria piscicida cell concentrations in field samples when compared to microscope counts. Microscopic counts of field samples, in addition to being tedious and time consuming, introduce several sources of error due to small sampling size and subsampling variation between aliquots. PCR-FFD eliminates sources of error due to sampling size and increases the sensitivity of detection 3 orders of magnitude from about 10 cells ml ${ }^{-1}$ to 10 cells $l^{-1}$. The increased specificity of PCR-FFD, when using the Pfiesteria-specific primer and protocol described here, is also evident in the DGGE analysis of PCR products. Although PCR-FFD was used here to enumerate all strains of Pfiesteria in a sample, Pfiesteria strain-specific primers may be designed to quantify each strain separately. Alternatively, Pfiesteria strains may be identified and enumerated using restriction endonucleases that recognize restriction sites unique to each strain. Digestion of the PCR products prior to GeneScan analysis would allow us to discriminate between strains (Liu et al. 1997).

To demonstrate the utility of PCR-FFD we conducted a diel study of Pfiesteria piscicida abundance in correlation to other physical, chemical and biological variables. Most previous studies of Pfiesteria abundance have focused on poorly flushed upper estuarine areas where toxic blooms are more likely to occur (Burkholder et al. 1995) and where cell numbers are often high enough for microscope counts. Our data, however, indicate that even in estuarine channels where tidal energy and water exchange are high, Pfiesteria is frequently present in background numbers as a minor but common component of Delmarva estuarine plankton communities. As with other planktonic organisms, our survey revealed considerable small-scale patchiness and variability in Pfiesteria abundance in this system. The regression coefficient (0.26) for Pfiesteria abundance and phosphate concentration suggests that about one-quarter of the variability in Pfiesteria abundance may be attributed to phosphate variability. Although there was some degree of correlation between Pfiesteria and biological variables (such as bacterial and chlorophyll concentrations) during our study, this relationship was weak. More work will be needed to definitively establish the roles of various factors in determining Pfiesteria abundance (including many not measured here such as organic nutrients, ammonium and phytoplankton community composition). The results of our PCR-FFD demonstration are not intended as a definitive study of the relationship between Pfiesteria and environmental variables. Rather, they serve to illustrate the unique potential of molecular technologies to investigate factors involved in regulating the abundance of $P$. piscicida and other noxious and potentially toxic species, and to suggest directions for future research using PCR-FFD and DGGE methodologies.

Acknowledgements. The authors are grateful to Joann Burkholder, North Carolina State University, Raleigh, North Carolina, for Pfiesteria cultures; Edythe Humphries and Ellen Dickey, Delaware Department of Natural Resources and Environmental Control (DNREC), Dover, Delaware, for assistance in collecting water and sediment samples from the Delaware Inland Bays; Pat Glibert, University of Maryland Center of Environmental Sciences, Maryland, for water samples provided from the Pocomoke River; and to Yaohong Zhang and Brian Keuski for technical assistance. This work was supported by grants from NOAA/ECOHAB (NA 860P0495, ECOHAB Contribution \#24), Delaware Center of Inland Bays/EPA (LTR19991109) and Delaware's Sea Grant Program matching grant (NA96RG0029).

\section{LITERATURE CITED}

Anderson DM (1989) Toxic algal blooms and red tides: a global perspective. In: Okaichi T, Anderson DM, Nemoto $\mathrm{T}$ (eds) Red tides: biology, environmental science and toxicology. Elsevier Science Publishing Co, New York, p 11-16

Bowers HA, Tengs T, Glasgow HB Jr, Burkholder JM, Rublee PA, Oldach DW (2000) Development of real-time PCR assays for rapid detection of Pfiesteria piscicida and related dinoflagellates. Appl Environ Microbiol 66:4641-4648

Burkholder JM, Glasgow HB Jr (1997a) Pfiesteria piscicida and other Pfiesteria-like dinoflagellates: behavior, impacts, and environmental controls. Limnol Oceanogr 42: 1052-1075

Burkholder JM, Glasgow HB Jr (1997b) Trophic controls on stage transformations of a toxic ambush-predator dinoflagellate. J Eukaryot Microbiol 44:200-205

Burkholder JM, Glasgow HB Jr, Hobbs CW (1995) Fish kills linked to a toxic ambush-predator dinoflagellate: distribution and environmental conditions. Mar Ecol Prog Ser 124: 43-61

Burkholder JM, Noga EJ, Hobbs CH, Glasgow HB Jr (1992) New 'phantom' dinoflagellate is the causative agent of major estuarine fish kills. Nature 358:407-410

Carter HH (1967) A method for predicting brood stock requirements for oyster producing areas with application to the Monokin River. John Hopkins Univ Chesapeake Bay Inst Rep 13:46

Dempster EL, Pryor KV, Francis D, Young JE, Rogers HJ (1999) Rapid DNA extraction from ferns for PCR-based analyses. Biotechniques 27:66-68 
Dewitt P, Daiber FC (1973) The hydrography of the Broadkill River Estuary, Delaware. Chesapeake Sci 14:28-40

Gallagher JC (1982) Physiological variation and electrophoretic banding patterns of genetically different seasonal populations of Skeletonema costatum (Bacillariophyceae). J Phycol 18:148-162

Gallagher JC (1998) Genetic variation in harmful algal bloom species: an evolutionary ecology approach. In: Anderson DM, Cembella AD, Hallegraeff GM (eds) Physiological ecology of harmful algal blooms. Springer-Verlag, Berlin, p 225-242

Glasgow HB Jr, Burkholder JM, Schmechel DE, Tester PA, Rublee PA (1995) Insidious effects of a toxic estuarine dinoflagellate on fish survival and human health. J Toxicol Environ Health 46:501-22

Grattan LM, Oldach D, Tracy JK, Greenberg DR (1998) Neurobehavioral complaints of symptomatic persons exposed to Pfiesteria piscicida or morphologically related organisms. Md Med J 47:127-129

Guillard RRL (1975) Culturing of phytoplankton for feeding marine invertebrates. In: Smith WL, Chanley MH (eds) Culturing marine invertebrate animals. Plenum Publishing Co, New York, p 29-60

Hobbie JE, Daley RJ, Jasper S (1977) Use of Nucleopore filters for counting bacteria by fluorescence microscopy. Appl Environ Microbiol 33:1225-1228

Horsley \& Witten Inc (1998) Assessment of nitrogen loading to the Delaware Inland Bays. Report to the Delaware Inland Bays National Estuary Program, Nassau, DE

Lewitus AJ, Jesien RV, Kana TM, Burkholder JM, Glasgow HB Jr, May E (1995) Discovery of the 'phantom' dinoflagellate in Chesapeake Bay. Estuaries 18:373-378

Liu WT, Marsh TL, Cheng H, Forney LJ (1997) Characterization of microbial diversity by determining terminal restriction fragment length polymorphisms of genes encoding 16S rRNA. Appl Environ Microbiol 63:4516-4522

Lu W, Han DS, Yuan J, Andrieu JM (1994) Multi-target PCR analysis by capillary electrophoresis and laser-induced fluorescence. Nature 368:269-271

Mackenzie L, White D, Oshima Y, Kapa J (1996) The resting cyst and toxicity of Alexandrium ostenfeldii (Dinophyceae) in New Zealand. Phycologia 35:148-155

Maidak L, Cole JR, Parker CT Jr, Carrity GM, Larsen N, Li B, Lilburn TG, McCaughey MJ, Olsen GJ, Overbeek R, Pramanik S, Schmidt TM, Woese James MTACR (1999) A new version of the RDP (Ribosomal Database Project). Nucleic Acids Res 27:171-173

Maryland Department of Natural Resources (1997) Report of the Governor's Blue Ribbon Citizen's Pfisteria Action Committee, Nov 3, 1997. http://www.dnr.state.md.us/Hot/ contents.html

Medlin L, Elwood HJ, Stickel S, Sogin ML (1988) The characterization of enzymatically amplified eukaryotic 16S-like rRNA-coding regions. Gene 71:491-499

Miller RW (1989) Fish kill. Del Conservationist 32:38-40
Muyzer G, De Waal ED, Uitterlinden AG (1993) Profiling of complex microbial populations by denaturing gradient gel electrophoresis analysis of polymerase chain reactionamplified genes coding for 16S rRNA. App Environ Microbiol 59:695-700

Oldach DW, Delwiche CF, Jakobsen KS, Tengs T, Brown EG, Kempton JW, Schaefer EF, Bowers HA, Glasgow HB Jr, Burkholder JM, Steidinger KA, Rublee PA (2000) Heteroduplex mobility assay-guided sequence discovery: elucidation of the small subunit (18S) rDNA sequences of Pfisteria piscicida and related dinoflagellates from complex algal culture and environmental sample DNA pools. Proc Natl Acad Sci USA 97(8):4303-4308

Parsons ML, Scholin CA, Miller PE, Doucette GJ, Powell CL, Fryxell GA, Dortch Q, Soniat TM (1999) Pseudo-nitzschia species (Bacillariophyceae) in Louisiana coastal waters: molecular probe field trials, genetic variability, and domoic acid analyses. J Phycol 35:1368-1378

Pinckney JL, Millie DF, Vinyard BT, Paerl HW (1997) Environmental controls of phytoplankton bloom dynamics in the Neuse River Estuary, North Carolina, U.S.A. Can J Fish Aquat Sci 54:2491-2501

Porcher C, Malinge MC, Picat C, Grandchamp B (1992) A simplified method for determination of specific DNA or RNA copy number using quantitative PCR and an automated DNA sequencer. Biotechniques 13:106-115

Price KS (1998) A framework for a Delaware Inland Bays environmental classification. Environ Monit Assess 51: 285-298

Rublee PA, Kempton J, Schaefer E, Burkholder JM, Glasgow HB Jr, Oldach D (1999) PCR and FISH detection extends the range of Pfiesteria piscicida in estuarine waters. Va J Sci 50:325-336

Scholin CA (1998) Development of nucleic acid probe-based diagnostics for identifying and enumerating harmful algal bloom species. In: Anderson DM, Cembella AD, Hallegraeff GM (eds) Physiological ecology of harmful algal blooms. Springer-Verlag, Berlin, p 337-349

Skov J, Lundholm N, Pocklington R, Rosendahl S, Moestrup O (1997) Studies on the marine planktonic diatom Pseudonitzschia. 1. Isozyme variation among isolates of $P$. pseudodelicatissima during a bloom in Danish coastal waters. Phycologia 36:374-380

Smith SW, Overbeek R, Woese CR, Gilbert W, Gillevet PM (1994) The genetic data environment. An expandable GUI for multiple sequence analysis. Comput Appl Biosci 10: 671-675

Strickland JDH, Parsons TR (1972) A practical handbook of seawater analysis. Fisheries Research Board of Canada, Ottawa

Weston RF Inc. (1993) Characterization of the Inland Bays Estuary. Report to the Delaware Inland Bays National Estuary Program, Dover, DE

Wood AM, Leatham T (1992) The species concept in phytoplankton ecology. J Phycol 28:723-729

Submitted: December 11, 2000; Accepted: January 25, 2001 Proofs received from author(s): July 11, 2001
Editorial responsibility: David Caron,

Los Angeles, California, USA 